\title{
Erratum to: Does the trophic habitat influence the biochemical quality of the gonad of Octopus vulgaris? Stable isotopes and lipid class contents as bio-indicators of different life-cycle strategies
}

\author{
Sílvia Lourenço • Luís Narciso • \\ Ángel F. Gonzalez • João Pereira • \\ Santiago Aubourg $\cdot$ José C. Xavier \\ Published online: 22 November 2013 \\ (C) Springer Science+Business Media Dordrecht 2013

\section{Erratum to: Hydrobiologia \\ DOI 10.1007/s10750-013-1717-0}

Due to an unfortunate turn of events, the penultimate author's surname appeared incorrectly in the original publication and should have read Aubourg. The correct representation of the authors' names is listed above and should be treated as definitive by the reader.

The online version of the original article can be found under doi:10.1007/s10750-013-1717-0.

S. Lourenço $(\bowtie) \cdot$ L. Narciso

Centro de Oceanografia, Laboratório Marítimo da Guia, Faculdade de Ciências, Universidade de Lisboa, Avenida Nossa Senhora do Cabo 939, 2750-374 Cascais, Portugal e-mail: salourenco@fc.ul.pt

S. Lourenço · Á. F. Gonzalez · S. Aubourg Instituto de Investigaciones Marinas de Vigo CSIC, C/Eduardo Cabello, 6, 36208 Vigo, Spain

S. Lourenço · J. Pereira

Departamento do Mar e Recursos Marinhos, Instituto Português do Mar e da Atmosfera, I.P.Avenida de Brasília, 1449-006 Lisbon, Portugal

J. C. Xavier

Department of Life Sciences, Institute of Marine Research, University of Coimbra, 3001-401 Coimbra, Portugal 